\title{
TRYPANOSOMIASIS CRUZI: A FOLLOW-UP STUDY OF TISSUE REACTING IMMUNOGLOBULINS IN INFECTED PUREBRED PINSCHER DOGS
}

\section{Eduardo Alves Bambirra1, Washington Luis Tafuri1, Luigi Bogliolo $\S$, Cléa Chiari2 and Fausto Edmundo Lima Pereira ${ }^{3}$}

\begin{abstract}
Antibodies against striated muscle (cardiac and skeletal) were studied in serum samples from 36 purebred prepubertal Pinscher dogs (15 controls without infection and 21 infected with Trypanosoma cruzi from 7 to 400 days after infection with 1000 trypomastigotes/gram body weight of the Colombiana strain by the intraperitoneal route). Although three different immunohistological patterns of tissue-reacting immunoglobulins were found their presence was not correlated with any peculiar characteristics or with the severity of the disease in each particular dog.
\end{abstract}

Key words: Experimental trypanosomiasis cruzi. Dog. Autoantibodies.

Tissue-reacting immunoglobulins.

The occurrence of autoantibodies has been reported during Trypanosoma cruzi infections in man and in experimental models. In man, an antibody reacting with endocardium, vascular structures and interstitium of striated muscle (EVI antibody) was found in some instances during Chagas' disease ${ }^{3}$. It has been shown that the involved antigen is located at the plasma membrane of striated fibers, and in endothelial cells of different mammalian tissues 5 .

In experimental infections, autoantibodies have also been reported in mice, rabbits and monkeys. In the mouse antinuclear antibodies could be found during the infection ${ }^{10}$. In rabbits a diffuse fluorescence was detected in the muscle structure of the heart, skeletal muscle and oesophagus, as well as in arteries from the brain and kidney 12 . It was recently shown that EVI

Trabalho dos Departamentos de Anatomia Patológica e Medicina Legal da Faculdade de Medicina da Universidade Federal de Minas Gerais 1 , de Parasitologia do Instituto de Ciências Biológicas da Universidade Federal de Minas Gerais ${ }^{2}$ e de Patologia da Universidade Federal do Espirito Santo ${ }^{3}$. Trabalho realizado com auxílio do CNPq e da FINEP.

\section{$\S$ "In memoriam"}

Endereço para correspondência: Dr. Bambirra, R. Turmalina, 274 - Prado; CEP 30000 - Belo Horizonte MG.

Recebido para publicação em 5/9/1983. and peripheral nerve antibodies, resembling those found in humans, were present in the serum of rhesus monkeys 11 .

The high susceptibility of dogs to $T$. cruzi infection was initially established by Chagas 4 and has been confirmed by others ${ }^{3}$. Earlier studies of the immunopathologic aspects of the interactions of $T$. cruz $i$ in dogs were limited to the work of Muniz et al ${ }^{7}$ and Costa \& Costa ${ }^{6}$ who described general aspects of the specific humoral immunity against $T$. cruz $i$ during the course of the infection. In the present paper we investigated whether tissue reacting immunoglobulins (autoantibodies) can occur in prepubertal purebred Pinscher dogs infected with the T. cruz $i$.

\section{MATERIALS AND METHODS}

Serum samples were obtained from 21 prepubertal purebred Pinscher dogs (Canis familiaris) infected by intraperitoneal route with 1000 trypomastigotes/gram per body weigth of $T$. cruzi, Colombiana strain. All of these dogs had positive anti $-T$. cruzi serology (indirect immunofluorescence technique IIFT) and positive parasitemia (direct examination of peripheral blood). The clinical findings, specific antibody response, hematological, radiological and electrocardiographic findings and morphological studies (optic and ultrastructural aspects) during the course of the experimental infection have already been described 2 . 
Bambirra EA, Tafuri WL, Bogliolo L, Chiari C, Pereira FEL. Trypanosomiasis cruzi: a follow-up study of tissue reacting immunoglobulins in infected purebred pinscher dogs. Revista da Sociedade Brasileira de Medicina Tropical 17: 205-208, OutDez, 1984

Sera collected from day 7 to day 400 after the infection were available from all the dogs. As controls, serum samples from each experimental dog before the infection, and samples obtained from another 15 uninfected prepubertal purebred Pinscher dogs were used. Sera from those dogs were kept frozen at $-20^{\circ} \mathrm{C}$ until tested by the indirect immunofluorescence test (IIFT) for homologous tissue-reacting antibodies using fluorescein labelled antidog IgA, IgG and IgM (Miles Research Laboratories, USA). As antigenic substrates to study autoantibodies, 2-4 micrometerunfixed cryostat sections of dog heart, kidney, intestine, skeletal muscle and sciatic nerve frozen together in the same block, were used. All tests were made using serial dilutions of the sera from 1:2 to 1:512. Controls of fluorescent conjugates were made by direct incubation with the substrate.

\section{RESULTS}

Sera from uninfected dogs had no anti-T. cruzi antibodies or autoantibodies. At various times postinfection, as indicated in Figure 1, sera of the dogs were examined for autoantibodies. Antistriated muscle antibodies were first detected 2 weeks after the infection, with the maximum titre of 256 . The specific class of the detected immunoglobulin is presented on Table 1. The IIFT - IgG remained elevated $(>64)$ in all positive dogs during the whole observation period (400 days) except in three dogs, in which autoantibodies decreased to titre of 16 in serum samples obtained from 200 to 400 days. Anti-T. cruzi antibodies simultaneously measured by IIFT were detected concurrently with antistriated muscle antibodies, with the maximum titres of 2,560 (IgM, $3^{\text {rd }}$ week of infection). The IIFT-IgA-anti-striated muscle were persistently negative in all sera (Table 1 ).

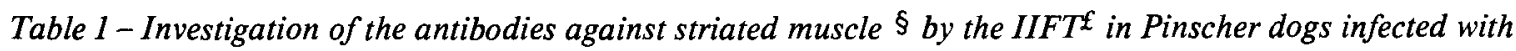
Trupanosoma crus:

\begin{tabular}{lcccc}
\hline \multirow{2}{*}{$\begin{array}{c}\text { Sera } \\
\text { (dilution }>1: 8)\end{array}$} & Number of & \multicolumn{2}{c}{ Antibodies to striated muscle } \\
\cline { 3 - 5 } & dogs & IgG alone & IgM alone & IgG + IgM \\
\hline Infected & 21 & $4(33,3 \%)$ & - & $8(66,7 \%)$ \\
Non-infected & 15 & & - &
\end{tabular}

$\S$ In each serum sample from the chagasic or the-infected dogs similar titres of skeletal and cardiac muscle autoantibodies were found.

$£$ Indirect immunofluorescence technique.

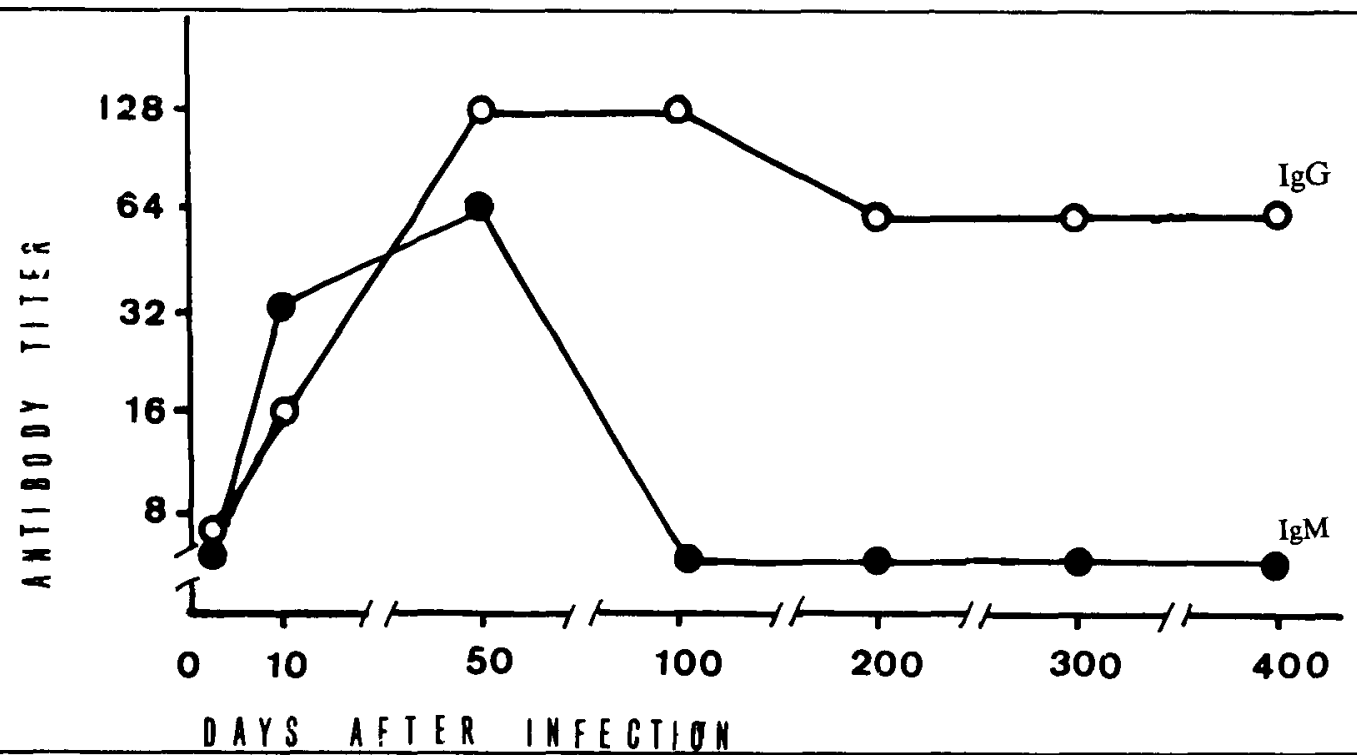

Figure 1 - Anti-striated muscle (skeletal and cardiac) antibodies in serial serum samples obtained from Pinscher dogs infected with $T$. cruzi. Each point represents the mean of 10 to 21 sera tested. 
Bambirra EA, Tafuri WL, Bogliolo L, Chiari C, Pereira FEL. Trypanosomiasis cruzi: a follow-up study of tissue reacting immunoglobulins in infected purebred pinscher dogs. Revista da Sociedade Brasileira de Medicina Tropical 17: 205-208, OutDez, 1984

Sera of all infected dogs were also examined for autoantibodies against liver, kidney, intestine (intramural autonomic nervous plexus) and peripheral nerve, and all the samples were negative.

The morphological study of the immunofluorescence histology of the autoantibodies against striated muscles (skeletal and cardiac) demonstrated three basic patterns: 1 . diffuse reaction on the myocell (Figure 2a); 2. endomysial and sarcolemmal reaction (Figure 2b); 3. myofibrillar reaction (Figure 2c).

During the period of observation we demonstrated changes of these morphological patterns in the same dog without apparent relationship with the concomitant clinico-laboratorial aspects of the disease. We could not correlate the titres of autoantibodies with the severity of the disease in each particular dog.

\section{DISCUSSION}

It has been suggested that autoantibodies can play a pathogenic role in Chagas' disease ${ }^{3}$. Although the possibility of linking the presence of tissue reacting immunoglobulins to the electrocardiographical abnormalities and to skeletal and cardiac muscle alterations found by histopathology and electron microscopy in these $\operatorname{dogs}^{2}$ is attractive, it is not known whether it is important in the pathogenesis of lesions or it is merely associated with it. However, the fact that clinical, immunological, electrocardiographical and morphological findings in Pinscher dogs infected with $T . c{ }^{2} u z i^{2}$ and the continued presence of tissue-reacting immunoglobulins are similar to the findings in human infection, indicated that this host is suitable for experimental immunopathologic studies of Chagas' disease. At present we do not know the pathogenic significance of the autoantibodies detected by immunofluorescence. The three detected patterns of depositon of the autoantibodies may reflect the variation of the release of the autoantigen in areas in the muscular tissue but we cannot correlate the morphological patterns of autoantibodies against striated muscle with some peculiar characteristic or with the severity of the disease in each particular dog, appraised by clinical, electrocardiographical, radiological and immunological methods (cellular and humoral immunity, endogenous and exogenous antigens, parasite and non-parasite related) and morphological studies (optical and ultrastructural aspects ${ }^{2}$ ), suggesting that the tissue reacting immunoglobulins represent only a epiphenomenon. We also cannot correlate the patterns and titres of the autoantibodies with the detected histopathological alterations and/or with the titres of specific anti $-T$. cruzi antibodies.
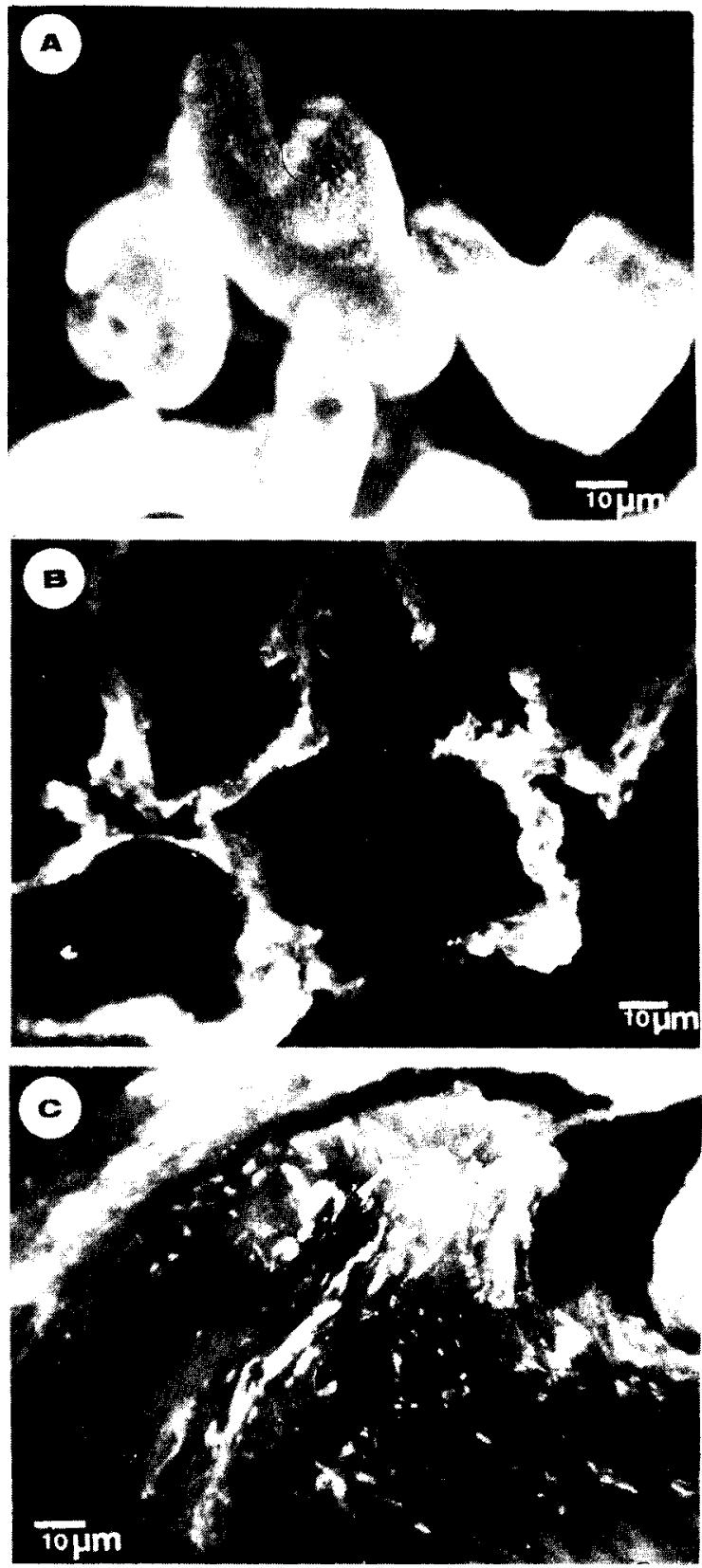

Figure 2 - Immunofluorescence patterns of autoantibodies against striated muscle (skeletal and cardiac) in Pinscher dogs infected with Trypanosoma cruzi: $a$ : diffuse reaction on the myocell; $b$ : endomysial and sarcollemmal reaction; $c$ : myofibrilar reaction.

Cross reactivity between $T$. cruzi and host tissue antigens ${ }^{9}$ or binding of parasite antigens to the host cells membranes 18 may well induce autoimmune phenomena in patients with Chagas' disease. However, some of the reactions detected on non- 
Bambirra EA, Tafuri WL, Bogliolo L, Chiari C, Pereira FEL. Trypanosomiasis cruzi: a follow-up study of tissue reacting immunoglobulins in infected purebred pinscher dogs. Revista da Sociedade Brasileira de Medicina Tropical 17: 205-208, OutDez, 1984

human substrates are probably due to heterophile antibodies and therefore unlikely to be of pathogenic significance, though they can be useful as immunological markers.

\section{RESUMO}

Foi investigada a presença de anticorpos contra músculo estriado (cardiaco e esquelético) em amostras de soro de 36 cães Pinscher de raça pura, pré-púberes (15 controles sem infecção e 21 infectados com Trypanosoma cruzi). A infecção foi feita atra vés de injeção intraperitoneal de 1.000 tripomastigotas/grama de peso e os cães foram examinados entre os dias 7 e 400. Três diferentes padrões de distribuição de imunoglobulinas nos tecidos foram demonstrados, embora nảo pudessem ser correlacionados com a característica da infeção ou com a gravidade da doença nos diferentes cães.

Palavras chaves: Doença de Chagas experimental. Cães. Auto-anticorpos. Imunoglobulinas em tecidos.

\section{REFERENCES}

1. Abrahamsohn JA, Kloetzel JK. Presence of Trypanosoma cruzi antigen on the surface of both infected and uninfected cells in tissue culture. Parasitology 80: 147$152,1980$.

2. Bambirra EA. Infecção experimental de cães Pinscher pelo Trypanosoma cruzi (Chagas, 1909): resposta imunitária ao parasita, a antigenos exógenos e de tecidos do hospedeiro, no decurso da evolução. Tese de doutorado. Universidade Federal de Minas Gerais, Belo Horizonte, 1982.

3. Brener Z. Immunity to Trypanosoma cruzi. Advances in Parasitology 18: 247-292, 1980.

4. Chagas C. Nova trypanosomiase humana. Ensaios sobre a morfologia e o ciclo evolutivo do Schizotrypanum cruzi n.gen., n. sp. ajente etiolojico de nova entidade mórbida do homem. Memórias do Instituto Oswaldo Cruz 1: 159 $218,1909$.

5. Cossio PM, Diez C, Szarfman A, Kreutzer E, Candiolo B, Arana RM. Chagasic cardiopathy: demonstration of a serum gamma globulin factor which reacts with endocardium and vascular structures. Circulation 49: 13-21, 1974.

6. Costa JF, Costa A. Verificações experimentais sobre imunidade humoral na doença de Chagas. Publicações Médicas (São Paulo) 31: 29-37, 1980.

7. Muniz J, Soares R, Quiroga L, Batista S. Evolução da imunidade humoral em cães infectados experimentalmente pelo Schizotrypanum cruzi. Revista Brasileira de Malariologia e Doenças Tropicais 5: 197-200, 1953.

8. Ribeiro dos Santos R, Hudson L. Trypanosoma cruzi: binding of parasite antigens to mammalian cell membranes: Parasite Immunology 2: 1-10, 1980.

9. Santos-Buch CA, Teixeira ARL. The immunology of experimental Chagas' disease. III-Rejection of allogenic heart cells "in vitro". Journal of Experimental Medicine 140: 38-53, 1974.

10. Szarfman A, Cossio PM, Laguens RP, De la Vega MT, Arana RM, Schmuñis GA. Immunological studies in Rockland mice infected with Trypanosoma cruzi. Development of anti-nuclear antibodies. Biomedicine 22: 489-495, 1975.

11. Szarfman A, Gerecht P, Draper CC, Marsden PD. Tissue-reacting immunoglobulins in Rhesus monkeys infected with Trypanosoma cruzi: a follow-up study. Transactions of the Royal Society for Tropical Medicine and Hygiene 75: 114-118, 1981 .

12. Teixeira ARL, Teixeira L, Santos-Buch CA. The immunology of experimental Chagas' disease in man. American Journal of Pathology 80: 163-178, 1975. 